\title{
PENGARUH PENGGUNA E-COMMERCE TERHADAP TRANSAKSI ONLINE MENGGUNAKAN KONFIRMASI FAKTOR ANALISIS
}

\author{
ACHMAD \\ Program Studi Informatika \\ Fakultas Teknik, dan Ilmu Komputer \\ Universitas Indraprasta PGRI \\ Jl. Nangka No. 58 C, Tanjung Barat, Jagakarsa, Jakarta Selatan 12530 \\ Email: achmad972@gmail. Com
}

\begin{abstract}
Abstrak. Dengan perkembangan Informasi teknologi dan Telekomunikasi, maka proses transaksi dapat dilakukan dengan online, Transaksi online adalah transaksi yang dilakukan penjual dan pembeli secara online melalui media internet, tidak ada perjumpaan langsung antara pembeli dan penjual. Dengan demikian maka akan berdampak langsung terhadap meningkatkan pangsa pasar. Sehingga ada pengaruh pengguna e-commerce dengan transaksi online, dan berdampak pada peralihan model transaksi yang sebelumnya dilakukan langsung menjadi proses tidak langsung dengan perantara aplikasi e-commerce. Dengan varibael laten dan dimensi konstruk maka rumusan masalah, adalah untuk mengukur indikator-indikator yang dikonsepsikan secara unidimensional, tepat, dan konsisten dan indikator-indikator ada yang dominan membentuk konstruk yang ditetili. sehingga alasan seseorang menjadikan tindakan/perilaku orang tersebut sebagai tolok ukur dalam penerimaan sebuah teknologi. Technology Acceptance Model (TAM) yang dikembangkan dari teori psikologis, menjelaskan perilaku pengguna komputer yaitu berlandaskan pada kepercayaan (belief), sikap (attitude), keinginan (intention), dan hubungan perilaku pengguna (user behaviour relationship Tujuannya untuk mengetahui konstruk atau variabel laten. Dengan mengkonfirmasikan atau menguji model pengukuran untuk mendapatkan konstruk atau variabel laten yang fit atau signifikan. Dari hasil pengujian dengan sampel 121 reposponden data yang telah di bersihkan dan diuji dengan metode Konfirmasi faktor analisis kedua variabel, dengan melihat nilai dimensi konstruk untuk E-Commerce yang mempengaruhi adalah harga yang ditawarkan $\mathrm{X} 1=0,878$, kenyamanan pada saat belanja X2 $=0,90$, kemudahan mencari produk $\mathrm{X} 4=0,802$. Kemudian untuk dimensi konstruk Transaksi Online yang mempegaruhi adalah melakukan transaksi online sekurang-kurangnya 1 minggu sekali X6 $=0,702$, sharing informasi yang dimiliki setelah melakukan tansaksi online X7 $=0,635$, dengan transaksi online dapat mencari yang dibutuhkan dalam pekerjaan $\mathrm{X} 8=0,782$. Hasil yang diperoleh menunjukan discriminant validity yang tinggi untuk varibel e-commerce dan transaksi online. Kedua konstruk menghasilkan nilai realibilitas konstruk diatas yang direkomendasikan $\geq 0,70$, jika dilihat dari hasil pehitungan Realilitas konstruk e-commerce 0,937 dan Realibilitas transakasi online 0,829. Untuk variance extracted konstruk e-commerce sebesar 0,902 dan Kontruk Transaksi online sebesar 0,787. Jadi nilai hasil Variance di rekomendasikan $\geq 0,5$ maka kedua konstruk e-commerce dan Transaksi di rekomendasikan.
\end{abstract}

Keyword : E-commerce, Transaksi online. Technology Acceptance Model (TAM)

\section{PENDAHULUAN}

E-commerce adalah electronic commerce, merupakan kumpulan teknologi, aplikasi, dan bisnis yang menghubungkan perusahaan atau perseorangan sebagai konsumen untuk melakukan transaksi elektronik, pertukaran barang, dan pertukaran informasi melalui internet atau televisi, www, atau jaringan komputer lainnya.Dengan perkembangan Informasi teknologi dan Telekomunikasi, maka saat ini membuka proses transaksi dapat dilakukan dengan online, Transaksi online adalah transaksi yang dilakukan penjual dan pembeli secara online melalui media internet, tidak ada perjumpaan langsung antara pembeli dan penjual. Dengan demikian maka akan berdampak langsung terhadap meningkatkan pangsa pasar. Di awal tahun 2017 ini, Menkominfo merilis data bahwa nilai transaksi online di Indonesia selama tahun 2016 mencapai 
angka US\$ 4,89 miliar, atau setara dengan Rp. 68 triliun. Angka ini tentunya masih merupakan angka perkiraan, karena menghitung setiap transaksi online di Indonesia bukanlah hal yang mudah. Tapi angka US\$ 4,89 miliar yang didapat selama 2016 ini jauh lebih tinggi daripada jumlah total transaksi pada tahun 2015 yang sebesar US\$ 3,56 miliar. (Sumber https://www.herosoftmedia.co.id/pengguna-internet-di-awal-tahun-2017-meningkat-51, diakses 12 Maret 2018). Semua orang yang ada di muka bumi dengan terhubung teknologi internet dapat memesan dan membeli produk yang dijual hanya dengan media komputer atau gadget. Untuk menurunkan biaya operasional pada saat transaksi dilakukan sebagian besar operasionalnya di program di dalam komputer sehingga biaya-biaya seperti tempat penjualan fisik seperti toko atau showroom tidak perlu perlu terjadi terutama perusahaan menyebabkan pengefisienan pada jumlah karyawan dan jumlah stok barang. Dan jangkauan penjualan secara global dapat diakses tidak terbatas tempat, waktu. Meningkatkan loyality pelanggan disebabkan karena sistem transaksi online menyediakan informasi secara lengkap. Sehingga memudahkan pelangan kapan saja mereka akan melakukan akses, tampa khawatir kalau penjualan melalui showrom atau toko tutup karena jam kerja. Berdasarkan data survey tahunan Apji 2016 Hasil survei internet yang berkaitan dengan e-Commerce, menunjukan bahwa 69,4\% atau 92 Juta pengguna menganggap aman untuk bertransaksi online. Tiga produk yang banyak dibeli online secara berurutan adalah tiket yakni $25,7 \%$ atau dibeli oleh 34,1 Juta Pengguna, Kebutuhan Rumah Tangga sebanyak 22,2\% atau dibeli oleh 29,4 Juta Pengguna dan Pakaian sebanyak 3,6\% atau dibeli oleh 4,7 Juta Pengguna (sumber http:// www.idea.or.id/berita/detail/hasilsurvei-internet-tahunan-apjii-2016, di akses 1 Nopember 2017). Menurut Sandhusen (2008), terdapat tiga pihak stakeholder dalam bisnis, yaitu: pertama, adalah pelaku bisnis, dalam hal ini perusahaan. Simbol untuk elemen ini adalah'B' (business). Kedua, adalah konsumen, yaitu pengguna bisnis barang dan jasa yang digambarkan dengan huruf ' $\mathrm{C}$ '. Terakhir, adalah pemangku kepentingan berupa pemerintah, yang digambarkan dengan huruf ' $G$ ' (government). Selanjutnya, jenis-jenis interaksi antara para pelaku bisnis dapat disimak pada tabel di bawah ini:

Tabel 1: Bentuk-Bentuk Interaksi di Dunia Bisnis

\begin{tabular}{|c|c|c|}
\hline No & Nama & Penjelasan \\
\hline 1 & B2B (Business to Business) & $\begin{array}{l}\text { Transaksi bisnis antara pelaku bisnis dengan pelaku } \\
\text { bisnis lainnya. Dapat berupa kesepakatan spesifik yang } \\
\text { mendukung kelancaran bisnis. }\end{array}$ \\
\hline 2 & B2C (Business to Consumer) & $\begin{array}{l}\text { Aktivitas yang dilakukan produsen kepada konsumen } \\
\text { secara langsung. }\end{array}$ \\
\hline 3 & $\begin{array}{l}\mathrm{C} 2 \mathrm{C} \quad \text { (Consumer } \\
\text { Consumer) }\end{array}$ & $\begin{array}{l}\text { Aktivitas bisnis (penjualan) yang dilakukan oleh } \\
\text { individu (konsumen) kepada individu (konsumen) } \\
\text { lainnya. }\end{array}$ \\
\hline 4 & o Business) & $\begin{array}{l}\text { C2B merupakan model bisnis dimana konsumen } \\
\text { (individu) menciptakan dan membentuk nilai akan } \\
\text { proses bisnis. }\end{array}$ \\
\hline 5 & B2G (Busines to Government) & $\begin{array}{l}\text { Merupakan turunan dari } \mathrm{B} 2 \mathrm{~B} \text {, perbedaannya proses ini } \\
\text { terjadi antara pelaku bisnis daninstansi pemerintah }\end{array}$ \\
\hline & $\begin{array}{l}\mathrm{G} 2 \mathrm{C} \text { (Government to } \\
\text { Consumer) }\end{array}$ & $\begin{array}{l}\text { Merupakan hubungan atau interaksi antara pemerintah } \\
\text { dengan masyarakat. Konsumen, dalam hal ini } \\
\text { masyarakat, dapat dengan mudah menjangkau } \\
\text { pemerintah sehingga memmperoleh kemudahan dalam } \\
\text { pelayanan sehari-hari. }\end{array}$ \\
\hline
\end{tabular}

Sumber: Sandhausen, 2008

\section{Rumusan Masalah}

Apakah indikator-indikator yang dikonsepsikan secara unidimensional, tepat, dan konsisten ? 
Apakah indikator-indikator ada yang dominan membentuk konstruk yang ditetili ?

\section{Tujuan Penulisan}

Bagi Akademik penelitian ini diharapkan bermanfaat untuk proses pembelajaran Untuk megentahui konstruk atau variabel laten. dengan mengkonfirmasikan atau menguji model pengukuran untuk medapatkan konstruk atau variabel laten yang fit atau signifikan sehingga dapat digunakan untuk analisis berikutnya, digunakan uji CFA (Confirmation Factor analysis).

\section{METODE}

Metode untuk melakukan penelitian ini dengan cara mengumpulkan data dari sumber data primer dan sekunder diolah dengan Amos system. penulis harus menentukan variabel manifes pada masing-masing konstruk tersebut. Beberapa model yang dibangun untuk menganalisis dan memahami faktor-faktor yang mempengaruhi diterimanya penggunaan teknologi komputer, di antaranya yang tercatat dalam berbagai literatur dan referensi hasil riset dibidang teknologi informasi adalah seperti Theory of Reasoned Action (TRA), Theory of Planned Behaviour (TPB), dan Technology Acceptance Model (TAM). Pada Model TAM sebenarnya diadopsi dari model TRA yaitu teori tindakan yang beralasan dengan satu premis bahwa reaksi dan persepsi seseorang terhadap sesuatu hal, akan menentukan sikap dan perilaku orang tersebut. Reaksi dan persepsi pengguna Teknologi Informasi (TI) akan mempengaruhi sikapnya dalam penerimaan terhadap teknologi tersebut. Salah satu faktor yang dapat mempengaruhinya adalah persepsi pengguna terhadap kemanfaatan dan kemudahan penggunaan TI sebagai suatu tindakan yang beralasan dalam konteks pengguna teknologi, sehingga alasan seseorang dalam melihat manfaat dan kemudahan penggunaan TI menjadikan tindakan/perilaku orang tersebut sebagai tolok ukur dalam penerimaan sebuah teknologi. Model TAM yang dikembangkan dari teori psikologis, menjelaskan perilaku pengguna komputer yaitu berlandaskan pada kepercayaan (belief), sikap (attitude), keinginan (intention), dan hubungan perilaku pengguna (user behaviour relationship) Tujuan model ini untuk menjelaskan faktor-faktor utama dari perilaku pengguna terhadap penerimaan pengguna teknologi. Secara lebih terinci menjelaskan tentang penerimaan TI dengan dimensi dimensi tertentu yang dapat mempengaruhi diterimanya TI oleh pengguna (user).

Adapun variabel manifes atau indikator yang digunakan dalam pengukuran masing- masing konstruk adalah sebagai berikut :

Tabel 2. Bangunan Model Teoritis

\begin{tabular}{ll}
\hline \multicolumn{1}{c}{ Varibel Laten } & \multicolumn{1}{c}{ Dimensi Konstruk } \\
\hline E-Commerce & X1 = Harga yang ditawarkan \\
X2 = Kenyamanan pada melakukan belanja & X3 = Kelengkapan Produk yang dijual \\
X4 = Kemudahan pencarian produk \\
X5 = Informasi yang diberikan E-commerce \\
Transaksi Online & X6 = Melakukan transaksi online sekurang-kurangnya 1 minggu sekali \\
& X7 = Sharing informasi yang dimiliki setelah melakukan tansaksi online \\
& X8 = Dengan transaksi online dapat mencari yang dibutuhkan dalam \\
pekerjaan & \\
X9 = Menyarankan penggunaan transaksi online bagi yang belum \\
menggunakan \\
X10 = E-Commerce mudah diakses untuk digunakan (X10)
\end{tabular}

Skala pengukuran menggunakan skor 1 sampai dengan 7 untuk setiap quesioner yang diberikan sesuai pengukuran konstruk diatas.

Model Kontruksi dapat digambarkan dengan system aplikasi Amos version 22, sesuai dengan variabel dan indikator yang dibuat sebagai berikut 


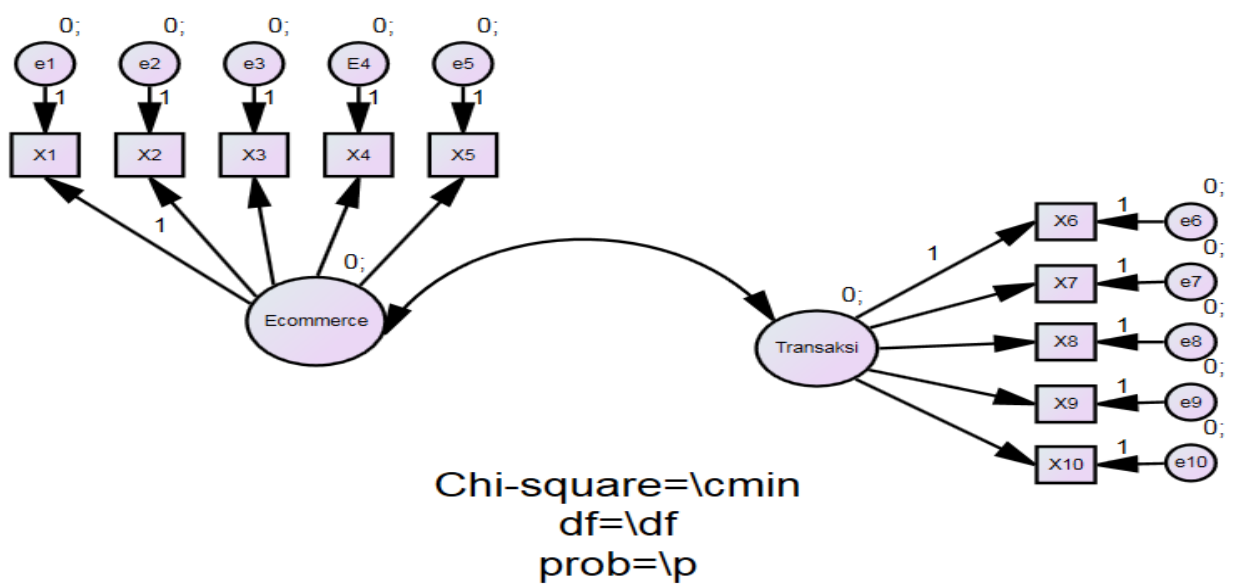

Gambar 1. Model Kontruksi CFA E-Commerce dan Transaksi

\section{Teknik Analisis Data}

Penulis menggunakan structural equation modeling (SEM) untuk melakukan analisis data. SEM adalah teknik statistik multivariat yang merupakan kombinasi antara analisis faktor dan analisis regresi (korelasi), yang bertujuan untuk menguji hubungan- hubungan antar variabel yang ada pada sebuah model, baik itu antar indikator dengan konstruknya maupun hubungan antara konstruk (Singgih Santoso 2012:1)

\section{Menentukan Degree of Freedom}

Dalam model SEM hal penting yang perlu diketahui sebelum melakukan pengujian model adalah model identification. Identifikasi berkaitan dengan apakah tersedia cukup informasi untuk mengidentifikasi adanya sebuah solusi dari persamaan structural .

\section{Dasar Penilaian dan Estimasi Model}

Setelah mengetahui besaran degree of freedom dan ternyata positif maka proses selanjutnya adalah mengumpulkan data dari sampel dan memasukkan ke dalam program AMOS. Setelah itu dilakukan proses penilaian (assessment) dan pengujian (estimation). Penilaian dimaksudkan untuk mengetahui sejauh mana data 'fit' dengan model yang sudah dibuat.

\section{Kovarian (Covariance)}

Kovarian merupakan alat utama untuk melakukan perhitungan dalam model SEM. Kovarian tersebut digunakan untuk melihat hubungan antar dua variable.

\section{Korelasi (Correlation)}

Korelasi juga merupakan alat statistik yang digunakan dalam analisa model SEM. Korelasi pada dasarnya adalah melakukan standarisasi pada hasil kovarians yang didapat. Namun berbeda dengan kovarians, angka korelasi dibatasi dari -1 sampai dengan +1 . Tanda ' + ' atau '-' menunjukkan arah hubungan dua variable, sedangkan

\section{Uji Validitas Measurement Model} besar angka dibelakangnya menunjukkan tingkat keeratan hubungan.

Measurement Model adalah bagian dari model SEM yang terdiri dari sebuah variable laten dan beberapa variable manifest yang menjelaskan variable laten tersebut. Tujuan pengujian adalah untuk mengetahui seberapa tepat variable-variabel manifest dapat menjelaskan variable laten yang ada. Adapun alat pengujian model yang digunakan adalah Absolute Fit Indices, Incremental Fit Indices dan Parsimony Fit Indices.

\section{Absolute Fit Indices}

Pengujian dengan alat uji ini akan membandingkan secara langsung matrik kovarians sampel dengan estimasi. Dengan demikian alat uji golongan ini adalah dasar dari semua alat uji yang lain. Salah satu alat uji goodness of fit utama pada absolute fit indices adalah CHI-SQUARE yang juga merupakan alat utama pengujian measurement model. 


\section{CHI-SQUARE}

Tujuan pengujian Chi-Square adalah untuk mengetahui apakah matriks kovarians sampel berbeda secara signifikan dengan matriks kovarian estimasi.

\section{Hipotesis :}

H0 : Matriks kovarian sampel tidak berbeda dengan matriks kovarians estimasi.

H1 : Matriks kovarians sampel berbeda secara signifikan dengan matriks kovarians estimasi.

Dengan melihat angka probabilitas (p) pada output AMOS

- Jika $\mathrm{p}>0,05$ maka H0 diterima

- Jika $\mathrm{p}<0,05$ maka H0 ditolak

\section{HASIL DAN PEMBAHASAN}

Sesuai dengan metode penelitian yang dilakukan maka untuk membahasnya digunakan SEM untuk analisis data. Jumlah Kusioner yang disebar sebanyak 145. Dari data yang sudah di terima dilakukan rekapulasi kemudian di cek data dengan aplikasi SPSS untuk melihat data outlier yaitu data yang nilainya lebih besar diantara nilai -2.5 sampai dengan 2.5. maka data yang nilai lebih besar di buang sehingga dari pengecekan jumlah data dari sebelumnya dari 145 sampel menjadi 121 sampel.

\section{Degree of Freedom}

Selanjutnya dalam menentukan degree of freedom (df) untuk mengetahui apakah model layak diuji atau tidak. dengan besaran df yang ditunjukkan dioutput Amos pada gambar 2 dibawah ini positif, maka model tersebut overidentified sehingga pengujian model tersebut dapat dilakukan. Namun pada hasil testing dengan amos didapatkan nilai Probability masih $=0,000$ ini artinya $\mathrm{P}<$ 0,05 maka Ho ditolak.

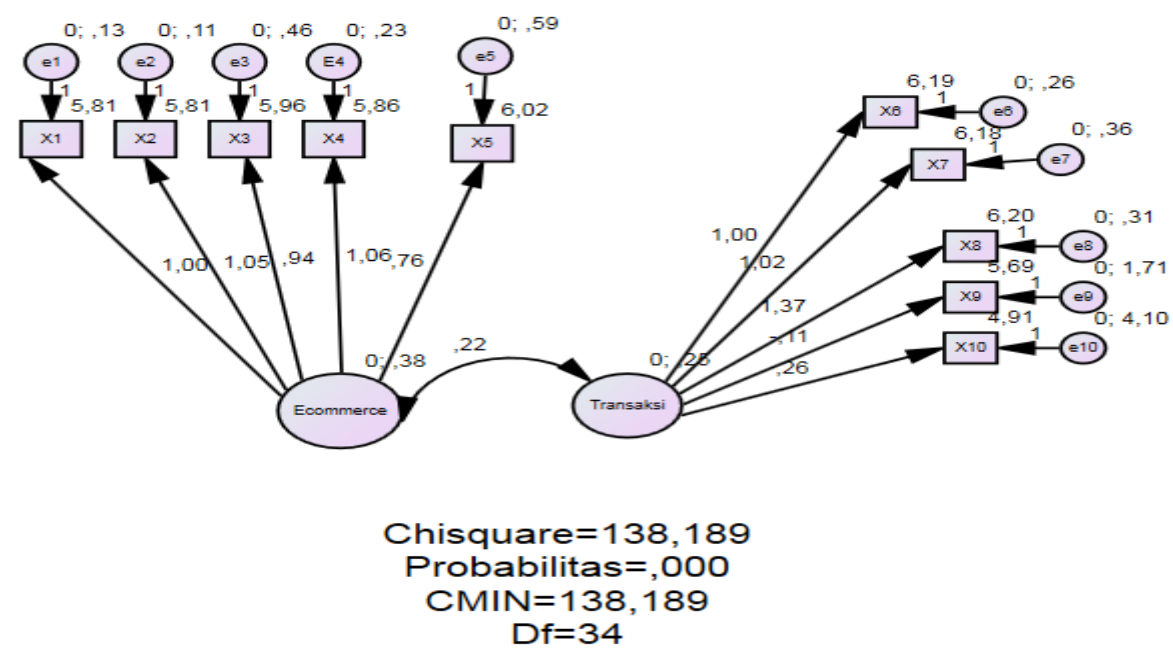

Gambar 2. Model Kontruksi CFA E-Commerce dan Transaksi

Kemudian Kita dapat melakukan perubahan model konstruk, dan dapat dilihat dari hasil output yang nilai variabel $<1,0$ dihilangkan variabel yaitu varibel X3, X5, X8, X9 dan X10. Sehingga model konstruk hasil perubahan dari running aplikasi amos analyze hasilya dapat dilihat pada gambar 3 dibawah ini 


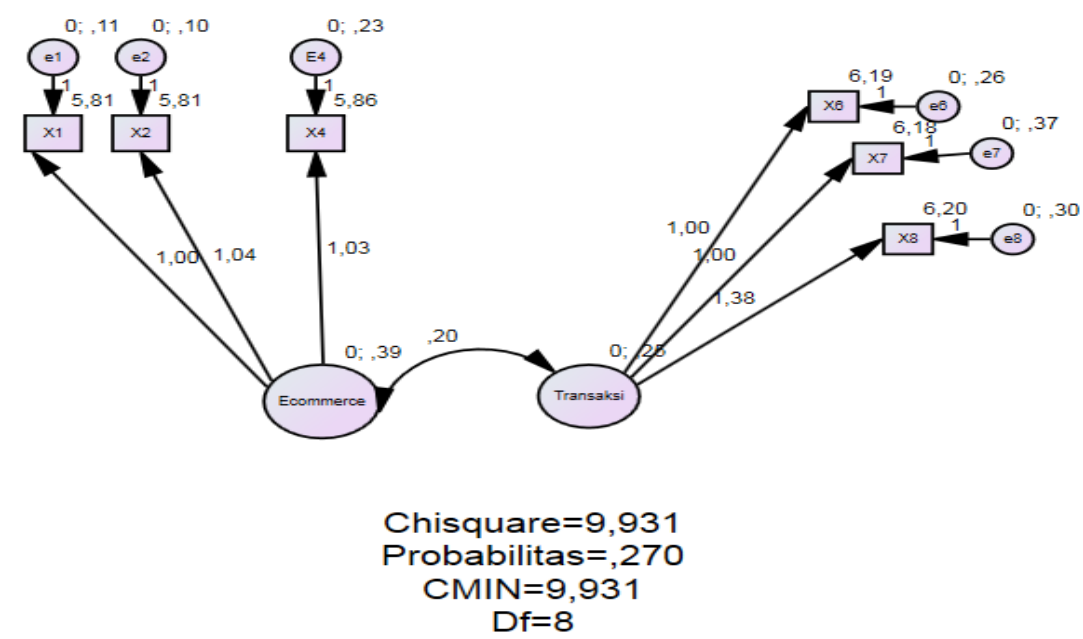

Gambar 3. Hasil perubahan Model Kontruksi CFA E-Commerce dan Transaksi

Dari Hasil diatas menunjukan nilai probabiltas sudah menunjukan nilai $>0,05$ maka Model konstruksi bisa di diterima. Dengan perubahan tersebut maka proses degre dapat dihasilkan seperti yang ada di gambar 4 dibawah ini, sebagai berikut

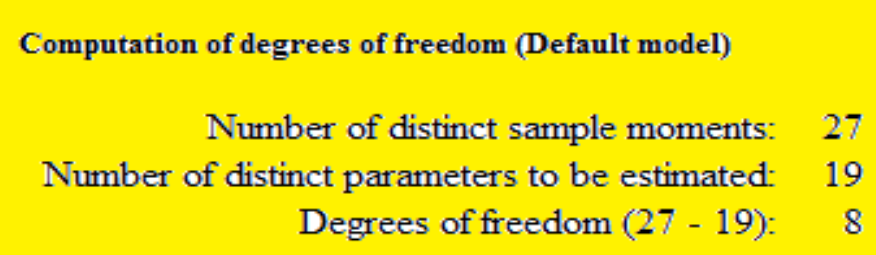

Gambar 4. Hasil Degree of Freedom

Dari hasil yang ditunjukan oleh ouput Amos Degree of freedom $=8$ positif maka model ini overindentified sehingga pengujian model tersebut dapat dilakukan.

Tabel 3. Regression Weights: (Group number 1 - Default model)

\begin{tabular}{lllllll}
\hline & & Estimate & S.E. & C.R. & P & Label \\
\hline X2 <--- & Ecommerce & 1,040 &, 081 & 12,902 & $* * *$ & par_1 \\
X6 <--- & Transaksi & 1,000 & & & & \\
X7 <--- & Transaksi &, 997 &, 169 & 5,885 & $* * *$ & par_2 \\
X8 <--- & Transaksi & 1,377 &, 212 & 6,487 & $* * *$ & par_3 \\
X4 <--- & Ecommerce & 1,034 &, 095 & 10,932 & $* * *$ & par_4 \\
X1 <--- & Ecommerce & 1,000 & & & &
\end{tabular}

Pengukuran model Fit

Dari hasil output amos overall model Fit kita terima, maka setiap kontsruk dapat dievaluasi secara terpisah pertama melihat signifikansi indokator loading dan ke dua melihat rehabilitas konstruk dan variabel exarated. Dengan melihat hasil c.r. untuk setiap loading menunjukan bahwa setiap variabel nilianya lebih besar dari niliasi kritisnya untuk tingkat siginikansi 0,05 (nilai kritis $=1,96$ ) dan tingkat signifikansi 0,01 (nilai kiritis $=2,576$ ) maka dapat disimpulkan bahwa semua variabel secara signifikan berhubungan dengan konstruk e-commerce dan konstruk transaksi online.

Stdandardzed Regression weight (group number 1-default mode) diatas 0,70 sehingga memenuhi kreteria indikator valid, namun untuk konstruk transaksi hanya ada satu indikator 
$\mathrm{X} 7$ yang dibawah 0,70 sedangan yang lainya diatas 0.70 . hasil dapat dilihat ditabel 4 dibawah ini

Tabel 4. Standardized Regression Weights: (Group number 1 - Default model)

\begin{tabular}{lll}
\hline & & Estimate \\
\hline X2 <--- & Ecommerce &, 900 \\
X6 <--- & Transaksi &, 702 \\
X7 <--- & Transaksi &, 635 \\
X8 <--- & Transaksi &, 782 \\
X4 <--- & Ecommerce &, 802 \\
X1 <--- & Ecommerce &, 879
\end{tabular}

Kelayakan parameter estimasi

Dari hasil nilai covariance jika ada nilia estimasi yang tidak memenuhi kriteria ini menunjukan indikiasi bahwa mungkin model salah atau matrix input tidak cukup memberikan informasi. Beberapa indikasi ini dapat dilihat jika nilai korelasi $>1,00$ Nilai Vaiance negatif dan matrix Kovarian atau korelasi tidak definit positive (not definite positive). Maka dari hasil output tabel dibawah ini pada tabel 5 nilai estimasi yang dihasilkan untuk covarian 0,202.

Tabel 5. Covariances: (Group number 1 - Default model)

\begin{tabular}{lllllll}
\hline & & Estimate & S.E. & C.R. & P & Label \\
\hline Transaksi <--> & Ecommerce &, 202 &, 043 & 4,653 & $* * *$ & par_5
\end{tabular}

Dibawah ini pada tabel 6 adalah hasil ouput Amos dapat dilihat hasilnya tidak ada menunjukan nilai negatif yang dikenal dengan heyword case.

Tabel 6. Variances: (Group number 1 - Default model)

\begin{tabular}{llllll}
\hline & Estimate & S.E. & C.R. & P & Label \\
\hline Ecommerce &, 391 &, 066 & 5,965 & $* * *$ & par_12 \\
Transaksi &, 249 &, 064 & 3,908 & $* * *$ & par_13 \\
e1 &, 115 &, 024 & 4,815 & $* * *$ & par_14 \\
e2 &, 099 &, 024 & 4,140 & $* * *$ & par_15 \\
e6 &, 257 &, 045 & 5,664 & $* * *$ & par_16 \\
e7 &, 366 &, 059 & 6,246 & $* * *$ & par_17 \\
e8 &, 301 &, 069 & 4,355 & $* * *$ & par_18 \\
E4 &, 232 &, 037 & 6,287 & $* * *$ & par_19
\end{tabular}

Tabel 7. Squared Multiple Correlations: (Group number 1 - Default model)

\begin{tabular}{ll}
\hline & Estimate \\
\hline X4 &, 643 \\
X8 &, 611 \\
X7 &, 404 \\
X6 &, 493 \\
X2 &, 810 \\
X1 &, 773
\end{tabular}

Maka diperlukan pengkuran realiblitas dan variance extraced setiap konstruk untuk menilai apakah indikator-indikator tersebut cukup mengambarkan konstruknya. Realibilitas konstruk dan variance extraced dihitung dengan rumus sebagai berikut 
Realibilitas Konstruk $=\underline{\text { Jumlah standard loading } 2}$

Jumlah standard loading ${ }^{2}+$ Jumlah Kesalahan Pengukuran

Untuk mendapatkan Jumlah standarr loading E-commerce dilakukan penjumlahan nilai X1 ditambah nilai X2 dan ditambah nilai X4 maka didapat nilai total 2,581 dapat dilihat pada tabel 8 dibawah ini.

Tabel 8. Jumlah Standard Loading E-commerce

\begin{tabular}{|c|c|c|c|c|}
\hline Variabel & $\mathrm{X} 1$ & $\mathrm{X} 2$ & $\mathrm{X} 4$ & $\begin{array}{l}\text { Nilai } \\
\text { Total }\end{array}$ \\
\hline e-Commerce & 0,879 & 0,9 & 0,802 & 2,581 \\
\hline
\end{tabular}

Untuk mendapatkan Jumlah standarr Transaksi online dilakukan penjumlahan nilai X6 ditambah nilai X7 dan ditambah nilai X8 maka didapat nilai total 2,119 dapat dilihat pada tabel 9 dibawah ini.

Tabel 9. Jumlah standard loading Transaksi online

\begin{tabular}{crrrr}
\hline Variabel & \multicolumn{1}{l}{ X6 } & \multicolumn{1}{l}{ X7 } & X8 & Nilai Total \\
\hline Transaksi online & 0,702 & 0,635 & 0,782 & 2,119
\end{tabular}

Untuk mendapatkan Jumlah Kesalahan Pengukuran E-commerce dilakukan penjumlahan E1, ditambah nilia E2 dan Ditambah nilai E3 maka didapat total nilai 0,466 dapat dilihat tabel 10 dibawah ini.

Tabel 10. Jumlah Kesalahan Pengukuran E-commerce

\begin{tabular}{crrrr}
\hline Variabel & \multicolumn{1}{l}{ E1 } & \multicolumn{1}{l}{ E2 } & \multicolumn{1}{l}{ E4 } & Nilai Total \\
\hline e-Commerce & 0,115 & 0,099 & 0,232 & 0,446
\end{tabular}

Untuk mendapatkan Jumlah Kesalahan Pengukuran transakasi omline dilakukan penjumlahan E6, ditambah nilia E7 dan Ditambah nilai E8 maka didapat total nilai 0,924 dapat dilihat tabel 11 dibawah ini.

Tabel 11. Jumlah kesalahan Pengukuran Transaksi Online

\begin{tabular}{crrrr}
\hline Variabel & E6 & E7 & E8 & Nilai Total \\
\hline Transasksi Online & 0,257 & 0,366 & 0,301 & 0,924
\end{tabular}

Selajanjutnya kita lakukan perhitungan realibilitas konstruk e-commerce dan transaksi online Realibilitas Konstruk E-Commerce $=(2,581)^{2}$

$$
\begin{aligned}
& (2,581)^{2}+0,446 \\
= & 0,937
\end{aligned}
$$

Realibilitas Konstruk Transaksi Online $=(2,119)^{2}$

$$
\begin{aligned}
& \frac{(2,119)}{(2,119))^{2}}+0,924 \\
= & 0,829
\end{aligned}
$$

Perhitungan variance extracted

Variance Extracted $=\underline{\text { Jumlah kwadrat standard loading }}$

VE E-Commerce

$$
\begin{array}{ll}
\text { VE E-Commerce } & \begin{aligned}
\text { Jumlah kwadrat standard loading }+ \text { Jumlah kesalahan pengukuran } \\
=
\end{aligned} \\
& =\underline{0,879^{2}+0,90^{2}+0,802^{2}} \\
& =\underline{\left(0,879^{2}+0,90^{2}+0,802^{2}\right)+0,446} \\
& =0,833 \\
& =\underline{0,702^{2}+0,635^{2}+0,782^{2}} \\
\text { VE Transaksi Onlie } & \left.=\underline{\left(0,702^{2}+0,635^{2}+0,782^{2}\right.}\right)+0,924
\end{array}
$$




$$
\begin{aligned}
& 1,508+0,924 \\
= & 0,620
\end{aligned}
$$

Kedua konstruk menghasilkan nilai realibilitas konstruk diatas yang direkomendasikan $\geq 0,70$, jika dilihat dari hasil pehitungan Realiilitas konstruk e-commerce 0,937 dan Realibilitas transakasi online 0,829 .

Discriminant validity :

Nilai akar kuadrat VAE antar Konstruk

E-commerce $=\sqrt{ } 0,833=0,902$

Transaksi online $=\sqrt{ } 0,620=0,787$

Untuk variance extracted konstruk e-commerce sebesar 0,902 dan Kontruk Transaksi online sebesar 0,787. Jadi nilai hasil Variance di rekomendasikan $\geq 0,5$ maka kedua konstruk ecommerce dan Transaksi di rekomendasikan.

Bandingkan nilai korelasi antar konstruk dibawah ini

Tabel 11. Correlations: (Group number 1 - Default model)

\begin{tabular}{lll}
\hline & Estimate \\
\hline Transaksi <--> & Ecommerce & ,646
\end{tabular}

Dari hasil Variance extracted bila dibandingkan pada tabel corellation Transaksi dan Ecommerce menupunyai nilai discriminant validity yang tinggi, karena nilai akar kuadrat ave ecommerce dan transaksi diatas nilai konstruk tersebut sebesar 0,646.

\section{PENUTUP}

Simpulan

Dari hasil yang telah dilakukan untuk model konstruk yang telah di uji dengan amos ada perubahan dari model awal yang mempunyai degre of freedom 34 , nilai probability 0,000 menjadi degre of freedom 8 dengan nilai probability 0,270 dengan melihat nilai dimensi konstruk untuk E-Commerce yang mempengaruhi adalah harga yang ditawarkan $\mathrm{X} 1=0,878$, kenyamanan pada saat belanja X2 $=0,90$, kemudahan mencari produk $X 4=0,802$. Kemudian untuk dimensi konstruk Transaksi Online yang mempegaruhi adalah melakukan transaksi online sekurang-kurangnya 1 minggu sekali X6 $=0,702$, sharing informasi yang dimiliki setelah melakukan tansaksi online $\mathrm{X} 7=0,635$, dengan transaksi online dapat mencari yang dibutuhkan dalam pekerjaan $\mathrm{X} 8=0,782$. Sehinga dengan model konstruk perubahan prosesnya bisa dilanjutkan pengukuran konstruk variabel dan dengan nilai kelayakan estimisasi parameter nilai covarian 0,202 dan nilai korelasi 0,646 maka hasilnya $<1,00$ memenuhi kriteria dan pengukuran nilai realibilitas konstruk e-commerce dan transaksi online kemudian dilanjutkan dengan pengukuran nilai disciriminant validity menujukan hasil diatas yang direkomendasikan realibilitas konstruk $\geq 0,70$ dan Discriminant Validity $\geq 0,50$ maka hasil yang diperoleh menunjukan discriminant validity yang tinggi untuk kedua variabel e-commerce dan transaksi online direkomendasikan.

\section{Saran}

Adapun saran yang diberikan oleh penulis dilakukan penambahan variabel yang lebih banyak dan variatiif sehingga dapat mendapatkan hasil yang variatif juga, seperti kualitas layanan, Kualitas Informasi, kecepatan barang diterima dan kemanfaatan sistem Informasi.

\section{DAFTAR PUSTAKA}

A.Rizal (2013). Analisis penerapan project management information system (pmis) menggunakan metode technology acceptance model (tam) studi kasus PT. Indosat, tbk. Tesis Universitas Mercubuana

Hengky Laten (2012). Structural Equation Modelling Konsep dan Aplikasi menggunakan Program LISREL 8.80, Penerbit Alfabeta Bandung Mahir Pradana (2015). Klasifikasi jenis-jenis bisnis e-commerce di indonesia. Jurnal Neo-Bis Volume 9, No. 2, Des 2015 
Money, W., Turner, A., (2004). "Application of the Technology Acceptance Model to a Knowledge Management System", In Proceedings of the 37th Hawaii International Conference on System Sciences

Prof. Dr. Siswoyo Haryono, MM, MPd. (2017) Metode SEM untuk pnelitian Manajemen AMOS LISREL PLS, Penerbit Lixima Metro Media

Sandhusen, Richard (2008). Marketing. Hauppauge, N.Y: Barron's Educational Series.p. 520. ISBN 0-7641-3932-0

Singgih Santoso (2012), Analisis SEM menggunakan AMOS. PT. Elex Media Komputindo Jakarta

Dr. Richardus Eko Indrajit (2002), Electronic Commerce-Strategi dan Konsep Bisnis di Dunia Maya, APTIKOM

http:// www.idea.or.id/berita/detail/hasil-survei-internet-tahunan-apjii-2016, di akses 1 Nopember 2017)

https://www.herosoftmedia.co.id/pengguna-internet-di-awal-tahun-2017-meningkat-51, diakses 12 Maret 2018 